(C) Group of authors, 2019

UDC 616.381-072.1.995.121

DOI - https://doi.org/10.14300/mnnc.2019.14111

ISSN - 2073-8137

\title{
EFFICIENCY OF RETRIEVAL BAGS FOR USE DURING LAPAROSCOPIC SURGERY TO REMOVE HYDATID CYSTS OF THE LIVER
}

\author{
Minaev S. V. ${ }^{1}$, Kirgizov I. V. ${ }^{2}$, Akselrov M. A. ${ }^{3}$, Gerasimenko I. N. ${ }^{1}$, \\ Shamsiev J. A. ${ }^{4}$, Bykov N. I. 5 , Grigorova A. N. 1, Muravyev A. V. 1 , \\ Tussupkaliyev A. B. ${ }^{6}$, Lukash Yu. V. ${ }^{7}$, Muravyeva A. A. \\ 1 Stavropol State Medical University, Russian Federation \\ 2 Russian Medical Academy of Postgraduate Education, Moscow, Russian Federation \\ ${ }^{3}$ Tyumen State Medical University, Russian Federation \\ ${ }^{4}$ Samarkand State Medical Institute, Republic of Uzbekistan \\ ${ }^{5}$ Regional Children's Clinical Hospital, Stavropol, Russian Federation \\ ${ }^{6}$ West Kazakhstan Marat Ospanov Medical University, Aktobe, Kazakhstan \\ ${ }^{7}$ Rostov State Medical University, Rostov-on-Don, Russian Federation
}

\section{ЭФФЕКТИВНОСТЬ ИСПОАЬЗОВАНИЯ \\ РАЗАИЧНЫХ ЭНАОКОНТЕЙНЕРОВ ПРИ ПРОВЕАЕНИИ ААПАРОСКОПИЧЕСКОЙ ЭХИНОКОККЭКТОМИИ ПЕЧЕНИ}

С. В. Минаев ${ }^{1}$, И. В. Киргизов ${ }^{2}$, М. А. Аксельров ${ }^{3}$, И. Н. Герасименко ${ }^{1,}$ Ж. А. Шамсиев ${ }^{4}$, Н. И. Быков ${ }^{5}$, А. Н. Григорова ${ }^{1}$, А. В. Муравьев ${ }^{1}$, А. Б. Тусупкалиев ${ }^{6}$, Ю. В. Аукаш ${ }^{7}$, А. А. Муравьева ${ }^{1}$

1 Ставропольский госуАарственный МеАицинский университет, Российская ФеАерация

2 Российская меАицинская акаАемия непрерывного профессионаАьного образования, Москва, Российская Фелерация

${ }^{3}$ Тюменский госуАарственный МеАицинский Университет, Российская ФеАерация

${ }^{4}$ СамарканАский госуАарственный меАицинский институт, Республика Узбекистан

5 Краевая Аетская клиническая больница, Ставрополь, Российская Фелерация

6 ЗапаАно-Казахстанский меАицинский университет им. Марата Оспанова, Актобе, Казахстан

7 Ростовский госуАарственный МеАицинский университет, Ростов-на-Аону, Российская ФеАерация

The effectiveness of various retrieval bags for extracting resected tissues during removal of hydatid cysts (HCs) of the liver in children was evaluated. This open, prospective study included 59 children with $\mathrm{HC}$ of the liver treated during 2010-2019. Multiport laparoscopic echinococcectomy was undertaken. Patients were divided into three groups depending on the type of retrieval bag used to remove chitinous sheaths and fibrous tissues of liver fragments: group 1, laparoscopic endobag without wire $(n=23)$; group 2, EndoCatch bag $(n=19)$; group 3, vacuum retrieval bag $(n=17)$. Mean duration of the laparoscopic procedure was $120 \mathrm{~min}$ (71-193 $\mathrm{min}$ ) in group 1; $92 \mathrm{~min}$ (59-168 $\mathrm{min}$ ) in group 2; and $75 \mathrm{~min}$ (56-105 min) in group 3 . The longest time required to extract the chitinous and fibrous membranes from the abdominal cavity reliably $(F=3.455, P=0.044)$ was $17.5 \pm 2.5$ min (group 1), and the shortest time was $8.7 \pm 2.0$ min (group 3). Complications occurred in four patients and were minor. There were no deaths. In conclusions, the choice of retrieval bags for use during laparoscopic surgery for removing $\mathrm{HC}$ of the liver is an important factor. Laparoscopic echinococcectomy with the use of the vacuum retrieval bag proved to be an effective, safe technique for addressing $\mathrm{HC}$ of the liver in children.

Keywords: retrieval bag, outcome, laparoscopy, hydatid cyst, liver, children

В работе определялась эффективность различных эндоконтейнеров для извлечения резецированных тканей при удалении эхинококковых кист печени у детей. В открытом проспективном исследовании 2010-2019 гг. приняли участие 59 детей с эхинококкозом печени. Выполнялась многопортовая лапароскопическая эхинококкэктомия. Пациенты были разделены на три группы в зависимости от типа эндоконтейнера, используемого для удаления хитиновой и фиброзной оболочек с резецируемой тканью печени: группа 1 - классический эндоскопический мешок ( $\mathrm{n}=23)$; группа 2 - эндоскопический мешок-сачок EndoCatch $(n=19)$; группа 3 - вакуумный эндокотейнер $(n=17)$. Средняя продолжительность лапароскопической процедуры в группе 1 составила 120 мин (71-193 мин), в группе 2 - 92 мин (59-168 мин) и в группе 3 - 75 мин (56-105 мин). Наибольшая длительность извлечения резецированного материала

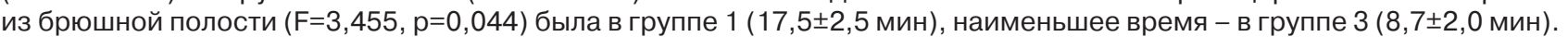
Осложнения возникли у 4 пациентов. Летальных исходов не отмечали. Таким образом, выбор лапароскопических эндоконтейнеров, используемых во время лапароскопического вмешательства, является важным фактором. Лапа- 
роскопическая эхинококкэктомия с использованием вакуумного эндоконтейнера оказалась наиболее эффективным и безопасным методом в лапароскопическом лечении эхинококкоза печени у детей.

Ключевые слова: эндоконтейнер, результаты, лапароскопия, эхинококкоз, печень, дети

For citation: Minaev S. V., Kirgizov I. V., Akselrov M. A., Gerasimenko I. N., Shamsiev J. A., Bykov N. I., Grigorova A. N., Muravyev A. V., Tussupkaliyev A. B., Lukash Yu. V., Muravyeva A. A. EFFICIENCY OF RETRIEVAL BAGS FOR USE DURING LAPAROSCOPIC SURGERY TO REMOVE HYDATID CYSTS OF THE LIVER. Medical News of North Caucasus. 2019;14(3):461465. DOI - https://doi.org/10.14300/mnnc.2019.14111

Для цитирования: Минаев С. В., Киргизов И. В., Аксельров М. А., Герасименко И. Н., Шамсиев Ж. А., Быков Н. И., Григорова А. Н., Муравьев А. В., Тусупкалиев А. Б., Лукаш Ю. В., Муравьева А. А. ЭФФЕКТИВНОСТЬ ИСПОЛЬЗОВАНИЯ РАЗЛИЧНЫХ ЭНДОКОНТЕЙНЕРОВ ПРИ ПРОВЕДЕНИИ ЛАПАРОСКОПИЧЕСКОЙ ЭХИНОКОККЭКТОМИИ ПЕЧЕНИ. Медицинский вестник Северного Кавказа. 2019;14(3):461-465. DOI - https://doi.org/10.14300/mnnc.2019.14111

ith the development of laparoscopy, the number and types of surgical interventions have increased to treat a large number of intra-abdominal diseases. Surgery for hydatid cysts (HCs) of the liver is an example [1]. Despite a fairly large number of currently used instruments, there are no structured approaches or analyses of the use of laparoscopic devices to safely remove resected tissues and parts of organs from the abdominal cavity $[2,3]$. Several endoscopic bags and containers are used in clinical practice, including the: classic retrieval bag and endobag (container-receiver) among others.

There is still no consensus from surgeons operating on adults and/or children regarding their preferred means to extract resected organs and tissues from the abdominal cavity [4]. This lack, in turn, leads to lengthening the time of manipulation and is also the cause of intraoperative and postoperative complications, including surgery of $\mathrm{HC}$ of the liver [5-7]. Hence, it is extremely important to develop endoscopic devices for extracting chitinous and fibrous membranes, taking into account not only the size and site of the parasitic cyst but also the life cycle of the parasite.

The aim of the present study was to evaluate the effectiveness of various retrieval bags for extracting resected tissues during the removal of $\mathrm{HC}$ of the liver in children.

Material and Methods. This open, prospective study included 59 children ( 36 boys, 23 girls; mean age $8.4 \pm 1.8$ years) with $\mathrm{HC}$ of the liver who presented during 2010-2019 (Table 1). All children underwent a standard set of clinical and laboratory tests as well as ultrasonography and computed tomography. The Gharbi classification approved by the WHO for echinococcosis was used to interpret the sonographic data regarding the cyst type. The multiport laparoscopic echinococcectomy that was performed was described previously [8].

Inclusion criteria were as follows: age 3-18 years; $\mathrm{HC}$ of the liver, Gharbi type I-III/CE1-3; cyst size $\geq 3 \mathrm{~cm}$. Exclusion criteria were the following: age $<3$ years; presence of combined forms of echinococcosis (e.g., liver and lung); presence of complicated forms of echinococcosis (e.g., breakthrough of the cyst into the biliary tract or abdominal cavity); cyst size $<3 \mathrm{~cm}$.

Laparoscopy was performed using three or four trocars depending on the location and volume of the $\mathrm{HC}$ The first 5- or 10-mm trocar was inserted in the umbilical area to accommodate a video camera. After auditing the abdominal cavity, we determined the presence and location of the $\mathrm{HC}$ in the liver to facilitate optimal access for one or two $5-\mathrm{mm}$ trocars in the right mesogastrium and one 12-mm Endopath Xcel port in the left or right mesogastrium (depending on the location of the $\mathrm{HC}$ in the liver). The cyst was overlaid with gauze napkins moistened with an anti-scolex solution (glycerol).

Table 1

Characteristics of all individuals undergoing a laparoscopic echinococcectomia of the Liver with the use of different kinds of retrieval bags between January 2013 and November 2017

\begin{tabular}{|l|c|}
\hline \multicolumn{1}{|c|}{ Indicators } & $\begin{array}{c}\text { № of patients } \\
(\mathrm{n}=59)\end{array}$ \\
\hline Age at operation (years) & $8.4 \pm 1.8(3-17)$ \\
\hline Sex ratio (B:G) & $36: 23$ \\
\hline $\begin{array}{l}\text { Hydatid cyst of the right/left } \\
\text { lobe of liver }\end{array}$ & $53 / 6$ \\
\hline $\begin{array}{l}\text { Type of the hydatid cyst: } \\
\text { Type I by Gharbi/CE1 }\end{array}$ & 23 \\
\hline Type II by Gharbi/CE & 21 \\
\hline Type III by Gharbi/CE3 & 15 \\
\hline $\begin{array}{l}\text { Type of a retrieval bags: } \\
\text { Laparoscopic Endobag } \\
\text { without wire }\end{array}$ & 23 \\
\hline EndoCatch Bag & 19 \\
\hline Vacuum Retrieval Bag & 17 \\
\hline
\end{tabular}

The cyst was punctured, and glycerol was injected. The cyst was exposed and its contents subsequently evacuated. With the help of a Harmonic ultrasonic scalpel and bipolar coagulation using Enseal, which allows manipulations at various angles, we evaluated the cyst's roof. Afterward, various kinds of retrieval bags were inserted via the $12-\mathrm{mm}$ trocar to evacuate the chitinous and fibrous membrane with fragments of the hepatic parenchyma. The basic rule was to evacuate one remote chitinous shell with one retrieval bag. After removing the pathological tissues and napkins around the intervention zone, revision of the residual area was carried out with argon-plasma coagulation of the surface, including any small bile fistulas. Control for haemostasis and bile flow was instituted. If necessary, a silicone drain was installed.

The patients were divided into three groups depending on the type of retrieval bag used to remove the chitinous sheath and fibrous tissues of the liver fragments: group 1: removal using the classic retrieval bag, a laparoscopic endobag without wire (Endomedium) $(n=23)$; group 2: removal using EndoCatch bag (Ethicon Endo-Surgery LLC) ( $n=19)$; group 3: removal using a vacuum retrieval bag (device for endoscopic recovery of infected biological material (Patent RU170304)) ( $n=17)$. 
The vacuum retrieval bag was a sterile polyvinylchloride (PVC) tube that we devised from a rectal tube Apexmed $36 \mathrm{CH} / \mathrm{Fr}$ (Apexmed International B. V., Amsterdam, The Netherlands) by removing its distal end and then rounding it off. We then cut perforations in the shape of a petal in the upper part of the tube (Figure). The vacuum retrieval bag was connected to the electrical pump via an adapter. Under camera control, the laparoscope was inserted through a 12-mm Endopath Xcel port into the abdominal cavity directly above the cyst. When the electrical pump was turned on, a negative pressure was created in the retrieval bag, causing absorption of the chitinous membrane, including the daughter cysts. During extraction of the contents, the pressure relief valve was pressed with the finger. If the cyst walls started to be suctioned, the vacuum was stopped inside the retrieval bag to avoid disturbing the adherent walls of the cyst. Because the vacuum retrieval bag is transparent, visual control was ensured when removing the material. After extracting the vacuum retrieval bag from the abdominal cavity, it was disconnected and discarded. In the case of incomplete extraction of material from the cyst cavity, a new vacuum retrieval bag was attached and the procedure repeated.

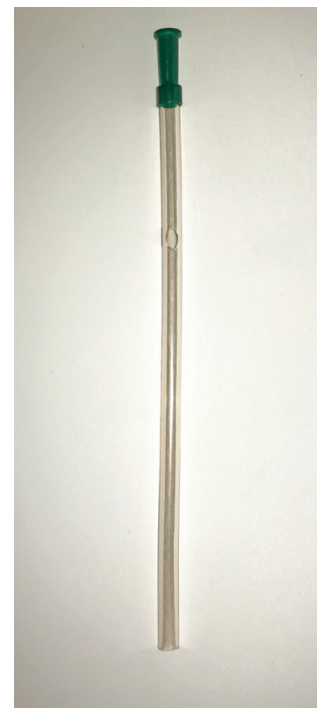

A

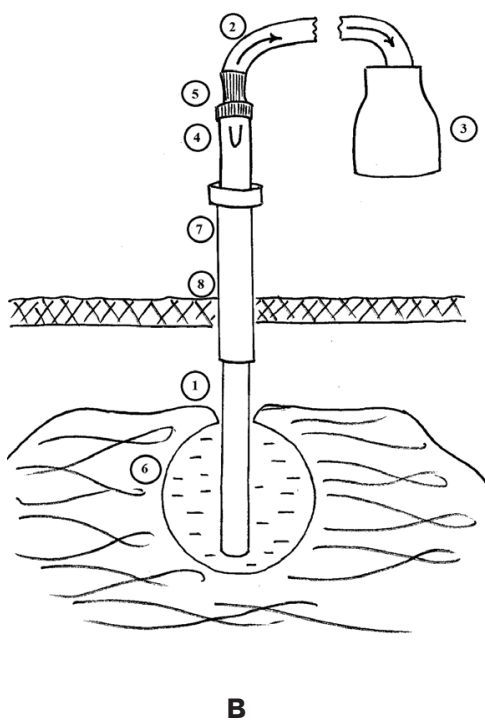

B
Fig. The Vacuum Retrieval Bag (A - Current Model,

B - Device Scheme): 1 - Vacuum Retrieval Bag; 2 - PVC Pipe leading to the Electric Pump; 3 - Vacuum Electric Pump; 4 - Pressure Relief Valve; 5 - Adapter for the connection of the Vacuum Retrieval Bag to the PVC pipe; 6 - Hydatid Cyst

of the Liver; 7 - Laparoscopic Port; 8 - Abdominal Wall

The distribution of parasitic cyst types was almost the same in the three groups: Type I HC was found in $23(38.9 \%)$ patients, type II in $21(35.6 \%)$, and type III in $15(25.4 \%)$. HCs were predominantly in the right lobe of the liver $(53,89.8 \%)$, most often in liver segments $\mathrm{VI}(23$, $38.9 \%)$ and VII (19, $35.8 \%)$.

The results obtained were evaluated according to the following indices: duration of the laparoscopic procedure (including extraction of the chitinous and fibrous membranes); number of ports and types of retrieval bags used during the operation, depending on the type of parasitic cyst; intraoperative and postoperative complications.

Statistical analysis was carried out using the parametric Student's criterion and nonparametric $\chi^{2}$ test with
Statistica 10.0 (StatSoft, USA). A p value of $<0.05$ was considered to indicate statistical significance.

Results and Discussion. The duration of the laparoscopic procedure using the laparoscopic endobag without wire (group 1) was 120 (71-193) min; using the EndoCatch Bag (group 2), it was 92 (59-168) min; and using the vacuum retrieval bag (group 3), it was 75 (56105) $\mathrm{min}$.

The duration of reliable $(\mathrm{F}=3.455, \mathrm{P}=0.044)$ extraction of the chitinous and fibrous membranes from the abdominal cavity was different in the study groups (Table 2). The longest time was $17.5 \pm 2.5$ min (group 1), and the shortest was $8.7 \pm 2.0 \mathrm{~min}$ (group 3 ).

Table 2

The duration of the stage for the extraction of the chitinous shell and fibrous membranes, depending on the type of a retrieval bag $(n=59)$

\begin{tabular}{|c|c|c|c|c|}
\hline \multirow{2}{*}{$\begin{array}{c}\text { Type } \\
\text { of a retrieval } \\
\text { bag }\end{array}$} & \multicolumn{4}{|c|}{$\begin{array}{l}\text { Time of extraction of chitinous } \\
\text { and fibrous membranes (in min) }\end{array}$} \\
\hline & $\begin{array}{l}\text { Type I/ } \\
\text { CE1 } \\
(n=23)\end{array}$ & $\begin{array}{c}\text { Type } \\
\text { II/CE2 } \\
(n=21)\end{array}$ & $\begin{array}{c}\text { Type III/ } \\
\text { CE 3 } \\
(n=15)\end{array}$ & $\begin{array}{l}\text { Signifi- } \\
\text { cance }\end{array}$ \\
\hline $\begin{array}{l}\text { Laparoscopic } \\
\text { Endobag } \\
\text { without wire, } \\
\text { Endomedium } \\
(n=23)\end{array}$ & $\begin{array}{c}14.3 \pm 2.3 \\
(n=8)\end{array}$ & $\begin{array}{c}17.6 \pm 3.4 \\
(n=10)\end{array}$ & $\begin{array}{c}20.5 \pm 1.6 \\
(n=5)\end{array}$ & $\begin{array}{l}F=1.183 \\
P=0.346\end{array}$ \\
\hline $\begin{array}{l}\text { EndoCatch } \\
\text { Bag, Ethicon } \\
(n=19)\end{array}$ & $\begin{array}{l}9.1 \pm 1.9 \\
(n=8)\end{array}$ & $\begin{array}{c}12.4 \pm 3.7 \\
(n=7)\end{array}$ & $\begin{array}{c}15.1 \pm 2.5 \\
(n=4)\end{array}$ & $\begin{array}{l}F=0.849 \\
P=0.468\end{array}$ \\
\hline \multirow[t]{2}{*}{$\begin{array}{l}\text { Vacuum } \\
\text { Retrieval Bag } \\
(n=17)\end{array}$} & $\begin{array}{c}6.7 \pm 1.5 \\
(n=7)\end{array}$ & $\begin{array}{c}7.9 \pm 2.6 \\
(n=4)\end{array}$ & $\begin{array}{c}11.1 \pm 1.8 \\
(n=6)\end{array}$ & $\begin{array}{l}F=1.126 \\
P=0.371\end{array}$ \\
\hline & $\begin{array}{l}F=3.795 \\
P=0.077\end{array}$ & $\begin{array}{l}\mathrm{F}=2.217 \\
\mathrm{P}=0.160\end{array}$ & $\begin{array}{l}F=6.640 \\
P=0.020\end{array}$ & \\
\hline
\end{tabular}

Depending on the life cycle of the parasite, the duration of use of retrieval bags increased in all groups from type I/CE1 to type III/CE3: from 14.3 \pm 2.3 to $20.5 \pm 1.6 \mathrm{~min}(\mathrm{~F}=1.183, \mathrm{P}=0.346)$ in group 1 ; from $9.1 \pm 1.9$ to $15.1 \pm 2.5 \min (F=0.849, P=0.468)$ in group 2; and from $6.7 \pm 1.5$ to $11.1 \pm 1.8 \mathrm{~min}(\mathrm{~F}=1.126, \mathrm{P}=0.371)$ in group 3. Compared with groups 1 and 2, there was a significant $(F=6.640, P=0.020)$ reduction in the duration of this stage in group 3 in children with HC type III/CE 3.

The numbers of intraoperative retrieval bags used depending only on $\mathrm{HC}$ type were one bag for type I/CE $\mathrm{HC}$; two to three bags for HC type II/CE 2; and two to four bags for HC type III/CE 3.

The process of extracting the chitinous membrane with the help of a retrieval bag during laparoscopy consisted of three stages: stage I, inserting the retrieval bag through the port; stage II, opening the retrieval bag in the abdominal cavity and capturing the chitinous membrane in it; stage III, closing the retrieval bag and removing it through the port.

Depending on the type of retrieval bag used, each of the groups studied had its own peculiarities. As a rule, however, stage I comprised moving the retrieval bag through a 12-mm Endopath Xcel port, whichdid not differ among the groups. The duration of stage II was longest in group 1. Opening a classic Endobag without wire in the abdominal cavity required the use of three ports with two or three clamps, as well as fairly good dexterity when opening the bag and capturing the chitinous and fibrous membranes in the Endobag. The use of the EndoCatch Bag in group 2 required the use of two ports and one 
clamp to capture the chitinous and fibrous membranes. The least time was spent in group 3, using a vacuum retrieval bag.

Complications occurred in four patients and were minor. Port-site dehiscence that required intervention occurred in one $(7.7 \%)$ patient in group 1 with $\mathrm{HC}$ type III/CE3 when using two classic endobags without wire sequentially. In addition, a bile fistula was noted in one child $(7.7 \%)$ in group 1 at the stage of developing the technique, but it closed spontaneously. One child (10\%) in group 2 with $\mathrm{HC}$ type II/CE2 had a residual cavity that persisted for 1 year after the operation and thus required a repeat surgical intervention. Finally, one child $(9.1 \%)$ in group 3 had a hypertrophic scar at the 1-year follow-up. There were no deaths.

To date, several types of commercial retrieval bags have been used to capture and remove specimens from the abdominal cavity during laparoscopic surgery. They include such products as: endobags, the EndoCatch bag, the Endopouch (Ethicon, Somerville, NJ, USA), and the Pleatman Sac (Abbot Laboratories, Lake Bluff, IL, USA), among others. These retrieval bags, however, are available in only one size and are suitable only for older children. It is therefore difficult to handle the retrieval bags intracorporeally in small children because of the limited space available in the surgical field [2, 9]. In contrast, several self-designed retrieval bags, including condoms, surgical gloves, and reclosable zipper bags, have been used during laparoscopic surgery. Unfortunately, most of them do not have a closure mechanism around the opening of the bag $[10,11]$.

In a study by Kao et al. [12] patients underwent robot-assisted laparoscopic radical prostatectomy and laparoscopic adrenalectomy. The retrieval bag used was introduced into the peritoneal cavity via a $12-\mathrm{mm}$ port, and the specimen was enclosed with the use of two laparoscopic instruments. No complications were observed. In the experience of the authors, their retrieval bag can be safely removed from the abdominal cavity.

The drawback of the classic endobag without wire is the difficulty encountered when opening the retrieval bag and capturing the chitinous and fibrous membranes in it, which requires good manual skill by both surgeon and assistant. In addition, up to three clips and ports are needed for this stage of the surgery [5]. The EndoCatch bag has fewer drawbacks (the number of ports and the length of the stage), but it requires some experience when the cyst is being captured in the retrieval bag. The use of a vacuum retrieval bag also has its drawbacks. When the cyst is located on the diaphragmatic surface of the liver, especially the VIII segment, an additional trocar is required above the cyst or in close proximity to it. Sometimes, with $\mathrm{HC}$ of the liver type CE2-3, a dense chitinous sheath may encircle the vacuum retrieval bag inlet during vacuum creation. To solve this problem, we used a method by which the device was rotated clockwise with periodic discharge of the vacuum, thereby ensuring detachment of the chitin sheath from the fibrous capsule and its absorption into the vacuum retrieval bag.

The drawbacks of the classic endobag without wire and the EndoCatch bag were the difficulty of extracting them through the port with cysts of $>10 \mathrm{~cm}$ diameter. When using a vacuum retrieval bag in group 3 , because of the possibility of leakage of parasitic cyst contents, the port should be installed as far as possible above the heart.

A vacuum retrieval bag for endoscopic extraction of biological tissues from the abdominal cavity is an alternative technique for removing infected biological material. Because of the hermetic contact, complete removal of the components of the $\mathrm{HC}$ is ensured. In addition, only one port is required into the abdominal cavity above the pathological focus.

Minimally invasive surgical techniques for treating $\mathrm{HC}$ of the liver in the paediatric population are gaining advocates. There are still questions, however, among authors who deal with echinococcosis [13, 14]. When analysing the literature, we find increasingly more publications on laparoscopic treatment of $\mathrm{HC}$ of the liver (in 2016-2017 there were more than 45 publications). Hence, the question of whether performing laparoscopic echinococcectomy for $\mathrm{HC}$ of the liver is worthwhile is no longer valid for paediatric surgeons [15].

Laparoscopic removal of $\mathrm{HC}$ of the liver requires compliance with the basic principles of open surgery, including compliance with aparasiticity [16]. One study [17] proposed a device for safe echinococcectomy. The essence of their device is that the port is installed in the $\mathrm{HC}$ and the manipulator removes the chitinous membrane. The authors, however, did not indicate from what segments of the liver the chitinous membrane was removed or in what types of cyst it is possible. We have gained experience using the vacuum retrieval bag, which can be used to remove HCs of the liver (type I-III/CE1-3), and the arrangement of cysts on the visceral and diaphragmatic surface of the liver.

Laparoscopic echinococcectomy can be considered safe when all the principles of classic echinococcectomy are observed $[8,18,19]$. In this study, we evaluated the effectiveness of retrieval bags using several criteria. The obtained data will allow surgeons to choose differentially the appropriate type of retrieval bag to extract biological materials from the abdominal cavity.

Conclusions. Along with observing the principles of aparasiticity, an important indicator is the reduction in the duration of laparoscopic interventions. The choice of retrieval bags for use in laparoscopic surgery of $\mathrm{HC}$ of the liver is an important factor. In this case, it is necessary to take into account not only the size and site of the $\mathrm{HC}$ but also the life cycle of the parasite. Most preferable is the topical use of a vacuum retrieval bag, which not only reduces the duration of the laparoscopic procedure but the number of complications as well.

\section{Disclosures:}

The authors declare no conflict of interest.

Acknowledgment:

We thank Nancy Schatken, BS, MT(ASCP), from Edanz Group (www.edanzediting.com/ac) for editing a draft of this manuscript. 


\section{References}

1. El Malki H. O., Souadka A., Benkabbou A., Mohsine R. Ifrine L. [et al.] Radical versus conservative surgical treatment of liver hydatid cysts. Br. J. Surg. 2014;101:669675. https://doi.org/10.1002/bjs.9408

2. Venturella R., Rocca M. L., Lico D., La Ferrera N., Cirillo R. [et al.] In-bag manual versus uncontained power morcellation for laparoscopic myomectomy: randomized controlled trial. Fertil Steril. 2016;105:1369-1376. https://doi.org/10.1016/j.fertnstert.2015.12.133

3. Raheem A. Laparoscopic Treatment of Hepatic Hydatid Disease. World Journal of Laparoscopic Surgery. 2009;21:35-39.

4. Karabicak I., Yuruker S., Seren D. T., Kesicioglu T., Cinar H. [et al.] Single incision laparoscopic surgery for hepatic hydatid disease. Report of a case. Ann. Ital. Chir. 2013;84:4513 .

5. Gomez I., Gavara C. Review of the treatment of liver hydatid cysts. World J. Gastroenterol. 2015;21:124-131. https://doi.org/10.3748/wjg.v21.i1.124

6. Ibtisam M., Aljohani K. Tailgut Cyst and Perineal Hydatid Cyst: A Case Report with Multimodality Imaging Findings. Case Reports in Radiology. 2016;ID4212753,5. https://doi.org/10.1155/2016/4212753

7. Minaev S. V., Gerasimenko I. N. Up-to-date approaches in treatment of hydatid disease of the liver in childhood. Vestn. Khir. im. I. I. Grek. 2013;172(1):71-74. PMID: 23808232

8. Minaev S. V., Gerasimenko I. N., Kirgizov I. V., Shamsiev A. M., Bykov N. I. [et al.] Laparoscopic Treatment in Children with Hydatid Cyst of the Liver. World J. Surg. 2017;41: 3218-3223. https://doi.org/10.1007/s00268-017-4129-x

9. Chipde S. S., Yadav A., Ranjan P., Prakash A., Kapoor R. Total laparoscopic management of a large renal hydatid cyst by using hydatid trocar cannula system. J. Surg. Tech. Case Report. 2012;4:32-35 https://doi.org/10.4103/2006-8808.100351

10. Karthik S., Augustine A. J., Shibumon M. M., Pai M. V. Analysis of laparoscopic port site complications: A descriptive study. J. Min. Access. Surg. 2013;9:59-64. https://doi.org/10.4103/0972-9941.110964
11. Paradiso V. P., Nanni L. Pediatric laparoscopic cholecystectomy with $2.3 \mathrm{~mm}$ Percutaneous Surgical System (Mini Lap Oे ): A new frontier for pediatric mini laparoscopy? J. Ped. Surg. Case Reports. 2016;6:13-16. https://doi.org/10.1016/j.epsc.2016.02.001

12. Kao C., Cha T., Sun G., Yu D., Chen H. [et al.] Cost-effective homemade specimen retrieval bag for use in laparoscopic surgery: Experience at a single center. Asian Journal of Surgery. 2012;35:140-143. https://doi.org/10.1016/j.asjsur.2012.04.025

13. Ramachandran C. S., Goel D., Arora V. Laparoscopic surgery in hepatic hydatid cysts: a technical improvement. Surg. Laparosc. Endosc. Percutan Tech. 2001;11:14-18.

14. Alessandro M., Stefano L. Echinococcus multilocularis in North America: the great unknown. Parasite. 2014;21:73. https://doi.org/10.1051/parasite/2014069

15. Berchi F. Management of Hydatid Cysts. In: Saxena A., Höllwarth M. (eds) Essentials of Pediatric Endoscopic Surgery. Springer, Berlin, Heidelberg; 337-341. https://doi.org/10.1007/978-3-540-78387-9_48

16. Milićević M. Radical versus conservative surgical treatment of liver hydatid cysts (Br. J. Surg. 2014:101:669-675). Br. J. Surg. 2014;101:676. https://doi.org/10.1002/bjs.9487

17. Hemmati S. H. How to Build a Simple and Safe Laparoscopic Hydatid Evaluation System. Journal of the Society of Laparoendoscopic Surgeons. 2014;18:e2014.00314. https://doi.org/10.4293/JSLS.2014.00314

18. Minaev S. V., Gerasimenko I. N., Shchetinin E. V Schetinin V., Mishvelov A. E. [et al.] 3D reconstruction in surgery of hydatid cyst of the liver. Medicinskii vestnik Severnogo Kavkaza. - Medical News of North Caucasus. 2019;14(1.2): 220-223. https://doi.org/10.14300/mnnc.2019.14019

19. Nelson I., Enrico B. Cystic Echinococcosis. J. Clin. Microbiol. 2016;54:518-523

https://doi.org/10.1128/JCM.02420-15

\section{About authors:}

Minaev Sergey Viktorovich, MD, PhD, Professor, Head of the Department of pediatric surgery; tel.: +79624507653; e-mail: sminaev@yandex.ru; ORCID - 0000-0002-8405-602

Kirgizov Igor Vitalevich, MD, PhD, Professor, Professor of the Department of pediatric surgery; tel.: +79057720953; e-mail: drkirgizov@yandex.ru; ORCID - 0000-0001-5796-5266

Akselrov Mikhail Aleksandrovich, MD, PhD, Professor, Head of the Department of pediatric surgery; tel.: +79292694933; e-mail: akselerov@mail.ru; ORCID - 0000-0001-6814-8894

Gerasimenko Igor Nikolaevich, MD, Associate Professor of the Department of pediatric surgery; tel.: +79187704217; e-mail: igor9551@yandex.ru; ORCID - 0000-0003-3003-612X

Shamsiev Jamshid Azamatovich, MD, PhD, Professor, Head of the Department of pediatric surgery; tel.: +998979100041; e-mail: shamsiyevja@mail.ru

Bykov Nikolay Ivanovich, MD, Head of Department; tel.: +79624013911; e-mail: 26bykov@yandex.ru

Grigorova Alina Nikolaevna, postgraduate student of the Department of pediatric surgery; tel.: +79633877244; e-mail: alina.mashchenko@mail.ru; ORCID - 0000-0001-5020-232X

Muravyev Alexandr Vasilevich, MD, PhD, Professor, Professor of the Department of general surgery; tel.: +79624423406; e-mail: mur_50@mail.ru

Tussupkaliyev Assylbek Balashevich, PhD, Associate Professor, Head of the Department of pediatric surgery; tel.: +77015221273; e-mail: a.tusupkaliev@mail.ru

Lukash Yulya Valentinovna, MD, Associate Professor of the Department of pediatric surgery and orthopedics; tel.: +79281315119; e-mail: Lukash_yv@rostgmu.ru ORCID - 0000-0002-9265-580X

Muravyeva Alla Anatolyevna, MD, Assistant of Professor of the Department of anesthesiology

reanimatology and emergency medical care; tel.: +79624405116; e-mail: muravyeva81@mail.ru 